\title{
A CONDIÇÃO JURÍDICA DAS SACERDOTISAS DE VESTA
}

\author{
THE LEGAL STATUTE OF VESTAL VIRGINS
}

Eliane Maria Agati Madeira*

\begin{abstract}
Resumo:
O presente artigo tem por objetivo investigar a peculiaridade da condição jurídica das sacerdotisas Vestais que, em Roma, diferentemente das demais mulheres, não se submetiam à tutela e possuíam prerrogativas bastante amplas, como a capacidade testamentária.

Palavras-chave: Vestal. Tutela feminina. Condição jurídica da mulher. Incestum e stuprum.
\end{abstract}

\begin{abstract}
:
The purpose of this article is to examine the legal statute Vestal Virgins, which, in the Ancient Rome, differently of other women, were not subject to the tutel and had very large prerogatives, like testamentary capacity.
\end{abstract}

Keywords: Vestal Virgin. Legal statute. Vow of chastity. Women's guardianship.

\section{Introdução}

A profunda inter-relação que se estabeleceu na Antiguidade entre a religião e as instituições domésticas, sociais, jurídicas ${ }^{1}$ e políticas ${ }^{2}$ de Roma, torna extremamente frutífera a pesquisa que, partindo de um enfoque religioso, procure alcançar a repercussão de tal fenômeno nos demais âmbitos da vida romana. Orientados por esta postura metodológica, que poderíamos denominar de "visão utilitária ou instrumental" da religião e movidos pelo interesse, já manifestado em diversos outros artigos ${ }^{3}$ de nossa lavra, de

\footnotetext{
Doutora em Direito Civil e Direito Romano pela Faculdade de Direito da Universidade de São Paulo. Especialista em Direito Romano pela Universitá di Roma La Sapienza. Professora Titular de Direito Romano da Faculdade de Direito de São Bernardo do Campo.

1 Em que pese a tradicional distinção entre ius e fas atribuída aos romanos, pode-se observar a estreita relação entre direito e religião em diversas fontes jurídicas, como na célebre definição de jurisprudência oferecida por Ulpiano (D.1.1.10.2) "iuris prudentia est divinarum atque humanarum rerum notitia, iusti atque iniusti scientia" (jurisprudência é o conhecimento das coisas divinas e humanas, a ciência do justo e do injusto) ou na visão do jurista Celso que assemelha a função do jurisconsulto a de um sacerdote (D.1.1.1.1), assim como, entre outras, na constituição do Direito Público exposta por Ulpiano (D..1.1.1.2) "publicum ius in sacris, in sacerdotibus, in magistratibus constitit" (Direito Público se constitui nos sacra, sacerdotes e magistrados). Traduções de MADEIRA in Digesto de Justiniano. São Paulo: Revista dos Tribunais, 2000.

2 A religião, em Roma, identificava-se com a cidade e é vista como verdadeira forma de patriotismo.

3 MADEIRA, Eliane Maria Agati. Algumas considerações sobre a prática feminina de envenenamentos na Roma Republicana. Revista da Faculdade de Direito de São Bernardo do Campo, 2004; MADEIRA, Eliane Maria Agati. La lex Oppia et la condition juridique de la femme dans la Rome Républicaine. Revue Internationale des droits de l'antiquité, LI, Bruxelles, p. 87-99, 2004; MADEIRA, Eliane Maria Agati. Advogadas Romanas Republicanas artigo apresentado na 59 ème Séssion de la Société Fernand de Vischer pour l'Histoire des
} 
desvendar a condição jurídica da mulher em Roma, ${ }^{4}$ pareceu-nos oportuno investigar o estatuto jurídico das únicas sacerdotisas mulheres ${ }^{5}$ naquela civilização, as Vestais.

Desde a mais remota antiguidade, em Roma, conheciam-se práticas femininas de culto religioso. Nestas imperava uma verdadeira segmentação de acordo com a "categoria" à qual cada mulher pertencesse. Assim, a primeira distinção que se estabelecia para efeitos de práticas religiosas era entre mulheres virgens e casadas que cultuavam, respectivamente, a Fortuna virginalis e a Fortuna primigenia. Dentre as mulheres casadas, valorizavam-se aquelas que houvessem contraído apenas um matrimônio (univirae) às quais era reservado, dentre outros, o culto da Fortuna muliebris, da Pudicitia e da Bona dea. ${ }^{6}$ Às prostitutas destinava-se o culto da Fortuna virilis que ocorria nos banhos masculinos. ${ }^{7}$

No que diz respeito aos cultos em que participavam as Vestais, entretanto, observa-se um outro modo de participação feminina nos rituais, reservado exclusivamente àquelas sacerdotisas, as quais gozavam de reconhecimento público significativo. São elas, as Vestais, quem fazem os $\operatorname{sacra}^{8}$ e não quem se beneficiam deles. Nesse sentido, interessante atentar para o elenco de sacra popularia relacionado por Festo e para as classificações de Labeão, no seu livro De iure Pontificali, que justamente levam em conta ora os sujeitos no interesse de quem são feitos os sacra ora os sujeitos que fazem os sacra. $^{9}$

Droits de 1'Antiquité, 2005 e publicado na Revista da Faculdade de Direito da Universidade de São Paulo, São Paulo, v. 101, p.87-107, jan./dez. 2006.

4 Note-se que, de acordo com nossa concepção, não há propriamente como identificar, abstratamente, a condição jurídica da mulher em Roma. Tal fato deve-se a diversidade de papéis que as mulheres assumiram naquela sociedade ao longo dos séculos (de VIII a.C. até VI d. C.) e à multiplicidade cultural daquela civilização. Assim, parece-nos mais adequado identificar a condição jurídica da mulher livre enquanto mãe (mater), filha (filia), esposa (uxor), religiosa, profissional, etc. nos diferentes períodos políticos vivenciados por Roma e levando em consideração, sempre que possível, seu status social e familiar.

5 A despeito da existência de outras mulheres a participar de cultos religiosos romanos, ressalte-se que tais mulheres exerciam função meramente colaboradora, na qualidade de esposas de sacerdotes, como ocorre com a flaminica, esposa do flamen dialis (sacerdote de Júpiter), submetida, assim como seu marido, a algumas restrições relatadas por Aulo Gélio X, 15.

6 No que diz respeito ao Culto de Bona Dea (Cf. PICCALUGA, Giulia. Bona Dea. Due contributi allo studio del suo culto. "Studi e materiali di storia delle religioni" 35, 1964), ainda que bastante desconhecido de nós diversos de seus aspectos, sabe-se que dele participavam escravas, matronae e também as Vestais. Os ritos em sua homenagem ocorriam em primeiro de maio, no templo sub saxo no Aventino e, na noite entre 3 e 4 dezembro, no lar do supremo magistrado cum imperio, ocasião em que a esposa ou a mãe deste magistrado assumia posição de destaque na condução da cerimônia. Os homens eram excluídos destas celebrações.

7 CANTARELLA, Eva. L'ambiguo malanno. Milano: Einaudi, 1995. p. 171-172.

8 Cícero, de har. resp. 46, a propósito da participação das Vestais no culto de Bona Dea, relata: “...cum ibi in operto virgines pro populo Romano sacra facerent....".

9 Cf. CATALANO, Pierangelo. Populus Romanus Quirites. Torino: Giappichelli, 1974. p. 123. 
A peculiaridade da disciplina jurídica à qual as Vestais estavam submetidas levou a romanista italiana Cantarella ${ }^{10}$ a considerá-las, sob diversos aspectos, como mulheres "emancipadas". Com efeito, as Vestais gozavam de uma série de prerrogativas que as colocavam numa situação altamente privilegiada, no que diz respeito a diversos aspectos da vida privada e pública e interessa-nos, a seguir, identificá-los e compreendêlos.

2. O acesso à condição de Vestal e as atribuições das Vestais

Assim como em cada lar romano mantém-se um fogo sagrado aceso dia e noite em honra dos antepassados e diante dele se praticam os cultos domésticos, é no templo de Vesta, situado entre o Átrio de Vesta e a Régia, a sudoeste do Foro, que se encontra o fogo da cidade de Roma, cuidadosamente mantido pelas Vestais, sacerdotisas romanas que se ocupam de alguns dos sacra publica. O templo de Vesta foi considerado o "lar sagrado da cidade" (Vesta quasi focus urbis) por Cícero (De leg., 2,12).

Em tal templo, o usual plano retangular destes edifícios ${ }^{11}$ romanos foi substituído, em honra à divindade feminina Vesta, por um formato circular. Tal configuração, de acordo com o relato de Ovídio, ${ }^{12}$ nos Fastos, é uma reminiscência ao primitivo local de culto de Vesta, outrora realizado em uma choupana circular, ${ }^{13}$ na regia magna $^{14}$ do Rei romano Numa. Além disso, para reforçar sua explicação relativa a este peculiar aspecto templário, Ovídio enfatiza a correlação existente entre Vesta e a Terra, esta última arredondada como um globo e, de acordo com as crenças romanas, suspensa no universo. A origem do nome da deusa, segundo a frágil explicação etimológica de Ovídio (vi stare), também se relaciona ao fenômeno descrito de identidade entre a Terra e Vesta e seria uma alusão ao fato da Terra manter-se no universo por sua própria força. ${ }^{15}$ Já para Plutarco, ${ }^{16}$ que também procura explicação para o aspecto circular do Templo de Vesta, a motivação de Numa Pompílio ao decidir por tal forma não teria sido a representação da figura da Terra ou de Vesta, que com ela se identifica, mas o desejo de representar todo o

10 CANTARELLA, Eva. op. cit., p. 174.

11 Cf. BORNECQUE, Henri; MORNET, Daniel. Roma e os romanos: literatura, história, antiguidades. São Paulo: EDUSP, 1977. p. 78, os templos romanos são pequenos, pois acredita-se serem morada dos deuses. Lá apenas adentram os sacerdotes e as pessoas encarregadas de sua manutenção. O culto é celebrado do lado de fora, onde se encontra um altar.

12 OVÍDIO. Fastos, VI, 216-266.

13 Semelhantemente, como acentua PICCALUGA, Giulia. Bona Dea, cit., p. 200 e 227, n. 139, também o primitivo local de culto de Bona Dea ocorria em uma cabana, em meio ao bosque.

14 Palácio Real.

15 OVÍDIO. Fastos, VI: Stat vi terra sua; vi stando Vesta vocatur.

16 PLUTARCO. Numa, XI. 
universo, em cujo centro, crêem os pitagóricos, localiza-se o fogo. A Terra, de acordo com tal concepção, giraria suspensa ao redor deste fogo.

De acordo com a mitologia, Vesta, deusa do fogo doméstico, irmã de Juno e Ceres, é a terceira filha de Saturno e Ops. ${ }^{17}$ Dentre os irmãos, embora cortejada por Apolo e Netuno, foi a única que se recusou a contrair matrimônio, mantendo-se casta e sedentária no Olimpo. Não é ela representada por qualquer imagem, mas apenas pelo fogo. Os asnos eram os animais sagrados que lhes eram dedicados e que, por ocasião das Vestálias, em meados de junho, eram coroados de flores e dispensados de suas duras atividades laborativas. Segundo Ovídio, ${ }^{18}$ foram os zurros de um asno que teriam salvo a deusa Vesta do estupro de Príapo, daí a razão para serem tais animais reverenciados.

Eram seis as Sacerdotisas de Vesta que, escolhidas pelo Pontífice Máximo entre os seis e dez anos de idade, ${ }^{19}$ estavam incumbidas de zelar para que o público fogo sagrado não se apagasse. Cícero ${ }^{20}$ assim nos esclarece a propósito de suas funções: Virgines Vestales custodiunto ignem foci publici sempiternum (Compete às virgens vestais proteger a chama inextinguível do lar público).

Provinham as futuras sacerdotisas de todas as tribos romanas, conforme testemunha Festo. ${ }^{21} \mathrm{O}$ fogo do qual se ocupavam simbolizava as raízes e a própria identidade da cidade de Roma. ${ }^{22}$ Acreditava-se, de acordo com Cícero, ${ }^{23}$ que: "Salvo o Templo de Vesta com seu fogo sagrado, nós estaremos salvos" e que o referido templo congregasse os cidadãos, como se fosse o "lar sagrado da cidade". ${ }^{24}$

Além desta primordial tarefa, também a elas incumbia a confecção da mola $s a l s a,{ }^{25}$ espécie de bolo de farinha e de sal que tornava eficaz qualquer sacrifício público romano, garantindo-lhe a pureza, e que era colocado sobre a testa da vítima a ser imolada. Outras cerimônias, sacras e secretas, ${ }^{26}$ também eram de sua competência.

\footnotetext{
17 Ops é esposa de Saturno e deusa da abundância. Protetora da agricultura, fonte de fartura e de riquezas, cf. BRANDÃO, Junito de Souza. Dicionário Mítico-Etimológico da Mitologia e da Religião Romana. Petrópolis: Edunb, 1993.

18 OVÍDIO. Fastos, VI, 335-348.

19 A tenra idade na qual as Vestais iniciavam sua função levou PICCALUGA, Giulia. op. cit., p. 228 a considerálas depositárias de um papel novicial e, portanto, iniciático.

20 CÍCERO, De leg., 2,8.

21 Fest. p. 516 L.: ... sex Vestae sacerdotes constitutae sunt ut populus pro sua quisque parte haberet ministram sacrorum, quia civitas romana in sex est distributa partes, in primos secundosque Titienses, Ramnes, Luceres.

22 SCHEID, John. Roma al femminile, Claudia la vestale. Bari: Laterza, 1994. p. 11.

23 CÍCERO. Fil., 11,10: "Quo saluo, salui sumus futuri".

24 CÍCERO. De Leg., 2, 12: "Vesta quase focus urbis".

25 PLÍNIO. Hist. Nat., XVIII, 2,7-8.

26 PLUTARCO. Numa, IX.
} 
Em Gélio ${ }^{27}$ encontramos interessantes informações sobre diversos aspectos relativos à escolha das Vestais. De acordo com a tradição, o primeiro a ter escolhido uma Vestal teria sido o Rei Numa. ${ }^{28}$ Baseando-se o Autor de Noites Áticas nas informações trazidas por Antístio Labeão no seu liber de sacerdotibus de comentários ao direito pontifical, considerado por Aulo Gélio o mais exato de todos aqueles que se ocuparam deste tema, confirma o referido Autor que tais sacerdotisas eram escolhidas entre os seis e dez anos de idade. Acrescenta ainda alguns requisitos indispensáveis à seleção de tais meninas: ter ambos os pais vivos, não ser gaga ou surda e não sofrer de qualquer enfermidade corporal. Quanto a seus pais, estes não poderiam ter sido emancipados, ter sido escravos ou exercer uma profissão vil (sordida). Segundo Ateio Capitão, em sua obra De iure pontificio também citada por Gélio, somente a filha de um homem domiciliado na Itália poderia ser escolhida Vestal e aqueles casais que tivessem três filhos estariam assegurados de não terem alguma de suas filhas selecionada para tal nobre atividade. Feita a escolha, era a Vestal conduzida ao pórtico do templo de Vesta, à presença dos pontífices. A partir deste momento, sem que houvesse qualquer emancipação ou capitis deminutio, deixava de incidir sobre ela a patria potestas e adquiria a sacerdotisa o direito de testar.

Insiste Aulo Gélio no fato do processo de escolha da Vestal estar posteriormente regulamentado pela Lex Papia. Sabe-se que a Lex Papia de vestalium lectione limitou o direito do Pontífice Máximo à eleição das Vestais, permitindo que também o povo influísse (sortitio in contione) em tal decisão. É controverso se tal lei seja o produto de um plebiscito de C. Papius, tribuno em 65 a.C. , ou do tribuno Papius em 253 a.C, ano em que foi eleito o primeiro Pontífice Máximo plebeu Tiberius Coruncanius. ${ }^{29}$

De acordo com os procedimentos determinados por esta lei $^{30}$, o grande pontífice escolhia vinte meninas e, a seguir, diante de uma assembléia popular, sorteava uma delas, a qual era consagrada a Vesta. Nos tempos de Gélio, entretanto, o sorteio deixou de ser obrigatório, pois se um homem honesto procurasse o Pontífice Máximo e apresentasse

\footnotetext{
27 AULO GÉLIO, I, 12,1. Este romano letrado nasceu por volta de 130 d. C. e estudou em Atenas onde começou a redigir anotações que lhes seriam úteis em suas célebres Noites Áticas, na qual discorre, em vinte livros, sobre gramática, história, literatura, filosofia, direito e geometria, Cf. HUMBERT, Jules. Histoire illustrée de la littérature latine: précis méthodique. Paris/Toulouse: H. Didier, 1932.

28 Cf. BRANDÃO, Junito de Souza. op. cit., p. 308, o mito, no entanto, "fixa a criação do colégio das Vestais num período que antecede a fundação de Roma, uma vez que Amúlio obrigara sua sobrinha Réia Sílvia, a futura mãe de Rômulo e Remo, a tornar-se sacerdotisa da deusa do fogo sagrado, mas uma variante outorga ao rei Numa a honra de haver introduzido na Urbe o culto à chama que não podia extinguir-se".

29 ROTONDI, Giovanni. Leges publicae populi romani. Hildeshei: Olms, 1966. p. 376-377.

30 SACCHI, Osvaldo. Il privilegio dell'esenzione dalla tutela per le Vestali (Gai.1.145). Revue Internationale des Droits de L'antiquité, Liège, v. 3, n. 50, p. 317-359, 2003, p. 341 ressalta que a "Lex papia de vestalium electione constituisce uma sicura testemonianza del prevalere del potere politico su quello sacerdotale nella direzione della formazione di un culto statale".
} 
sua filha para o sacerdócio, o Senado poderia, preenchidos os demais requisitos de acesso à condição de Vestal, permitir que se dispensassem as formalidades da Lex Papia.

No primeiro livro de Fábio Pictor, ${ }^{31}$ De iuris pontificii, encontram-se as palavras, reproduzidas por Aulo Gélio, ${ }^{32}$ que o Pontífice Máximo deveria pronunciar ao consagrar uma jovem à Vesta:

Sacerdotem Vestalem quae sacra faciat, quae ius siet sacerdotem vestalem facere, pro Populo Romano quiritibus, uti quae optuma lege fuit, ita te, amata, capio.

Eu te escolho, amada, como uma sacerdotisa Vestal, para que cumpra os ritos sagrados. E assim a faço sacerdotisa vestal por direito, como que assim escolhida por uma máxima lei, no interesse do povo Romano do Quirites.

Embora se acredite, de acordo com a tradição, que a primeira Vestal teria se chamado Amata e que este nome perpetuou-se, como forma de designar, durante a consagração, qualquer futura Vestal, outra é a informação fornecida por Plutarco em Numa. Com efeito, atribui-se ao Rei Numa Pompílio a criação e a eleição do Colégio dos Pontífices. O Sumo Pontífice era responsável pela consagração das Vestais e guardião destas virgens sagradas. Conforme o Autor de Vidas Paralelas, as primeiras consagradas por Numa teriam sido Gegânia e Verênia e as segundas, Canuléia e Tarpéia. Em seguida, o Rei Numa teria escolhido mais duas sacerdotisas, totalizando o número de seis Vestais, que tradicionalmente foi mantido.

Tais vestais levavam existência de clausura durante os trinta $\operatorname{anos}^{33}$ em que deviam consagrar-se à divindade e, durante esse período, deviam manter-se castas, sob pena de serem enterradas vivas por ordem do grande pontífice, caso descumprissem tal voto.

Estima Plutarco que a exigência da virgindade destas sacerdotisas se relacionasse ao principal aspecto de suas funções, qual seja, a manutenção do fogo sagrado. Para ocupar-se de tal tarefa acreditava-se que fosse necessário ser, à semelhança do fogo, substância pura e incorruptível. A nobreza de caráter das Vestais, de acordo com aquela concepção, era eficazmente garantida por meio da manutenção de sua virgindade.

\footnotetext{
31 Fábio Pictor é o mais antigo dos historiadores romanos. Viveu por volta de 210 a.C. e escreveu os Anais da História Romana que abrangem episódios significativos desde a época de Rômulo até a sua própria. De tal obra restaram apenas poucos fragmentos.

32 AUlO GÉliO. Noites Áticas, I, 12.

33 Conforme Dionísio de Halicarnasso (Dion. Hal. I 26), no início, era de apenas cinco anos o tempo de sacerdócio das Vestais. Plutarco estima em trinta anos, por determinação do Rei Numa, o período de castidade das Vestais.
} 
Se, por ventura, o fogo fosse extinto, relata o referido Autor que este deveria ser reacendido, segundo um preciso e minucioso ritual que previa a utilização de raios puros do sol incidindo em um determinado vaso que contivesse qualquer matéria leve e seca, o qual funcionaria como um espelho.

O tempo transcorrido no sacerdócio era dedicado ao aprendizado, realização (facere sacra) e ensinamento (docere) ${ }^{34}$ dos rituais religiosos. Assim, nos primeiros dez anos de vida religiosa, as Vestais faziam tirocínio como sacerdotisas, em seguida punham em prática o aprendizado e nos dez anos restantes ensinavam as novatas. Decorrido este tempo, aquelas que desejassem se afastar teriam licença para casarem-se e dedicarem-se a uma nova vida. Mas, segundo Plutarco, ${ }^{35}$ foram poucas as que assim teriam procedido, pois o sentimento de arrependimento de algumas egressas teria incutido supersticioso temor nas demais de modo que muitas delas mantinham a virgindade até a morte e velhice.

De acordo com Aulo Gélio ${ }^{36}$, a primeira Vestal a ter recebido permissão para iniciar-se na vida profana após seu sacerdócio, na idade de quarenta anos, teria sido Caia Tarrácia. Esta sacerdotisa recebeu tal privilégio, e outros que serão analisados mais adiante ao discorrermos sobre a condição jurídica das Vestais, como recompensa aos serviços prestados ao povo romano, notadamente pela concessão do Campo Tiberino ou de Marte aos romanos. Em decorrência desta doação, como público reconhecimento da grandiosidade deste gesto e em agradecimento, mandou-se que uma estátua fosse erigida em sua homenagem, fato inusual, conforme testemunho de Plínio, transcrito a seguir.

Plínio, História Natural, XXXIV, XI (5)

Eu considero que foi concedida uma estátua à virgem vestal Caia Tarácia, com a permisssão de erigi-la onde esta desejasse, privilégio que não é menos honorável para ela que aquele de ter recebido, embora mulher, uma estátua em sua homenagem. Aqui estão, nos próprios termos dos Anais, porque ela obteve este privilégio: "por ter presenteado ao povo o Campo Tiberino".

A grande Vesta (Maxima Virgo) é quem preside as demais Vestais. Todas usavam véu e veste branca, ${ }^{37}$ debruada de púrpura. Consideradas símbolo da castitas e da pudicitia, ao iniciarem a vida sacerdotal lhes era cortado o cabelo de um modo especial e deveriam sempre fazer uso de um penteado denominado seni crines, que também era

\footnotetext{
34 No que diz respeito à típica atividade sacerdotal e suas semelhanças com as tarefas de um jurista romano, remetemos o leitor ao aludido fragmento de Ulpiano em D.1.1.1.1.

35 PLUTARCO. Numa, X.

36 AULO GÉLIO. Noites Áticas, VII, 7, 4.

37 BORNECQUE, Henri; MORNET, Daniel. op. cit., p. 76.
} 
utilizado pelas mulheres casadas. Em suas aparições públicas utilizavam um véu que lhes cobria a cabeça e que lhes caía até os ombros, denominado suffibulum.

No templo de Vesta há um quarto secreto onde são conservadas relíquias, como o palladium, ${ }^{38}$ velha estátua de madeira que representava Minerva e que teria sido trazida de Tróia por Enéias. De acordo com a tradição, o palladium garantiria o poder daquele que o possuísse e todos que ousassem olhar para esta estátua perderiam a visão. ${ }^{39}$

\section{A condição jurídica das Vestais}

As fontes que nos informam acerca do estatuto jurídico das Vestais são esparsas. Todas contribuem para demonstrar a especificidade das regras que disciplinam a condição jurídica destas sacerdotisas e que constituem, de acordo com nosso entendimento, verdadeiro ius singulare.

Certamente o prestígio de que gozavam as sacerdotisas de Vesta contribuiu para tal diferenciação. Horácio, ${ }^{40}$ por exemplo, ressalta a santidade das Vestais, designandoas virgines sanctae, virgens sagradas. Cícero ${ }^{41}$ considera a missão de uma Vestal como um sacerdócio santíssimo, sanctissimum sacerdotium.

As prerrogativas das Vestais dizem respeito a dois aspectos: sociais e jurídicos. No que concerne ao primeiro aspecto, todas ocupam lugar de honra nas festas e na rua. Quando saem do Atrium Vestae são precedidas pelos lictores, ${ }^{42}$ que conduzem o cortejo. Além disso, possuíam o privilégio de utilizar carruagem (vehiculum) nas ruas de Roma. $^{43}$

O poder e a autoridade das Vestais era considerado tão grandioso que acreditava-se que com uma simples oração pudessem elas impedir a fuga de um escravo ${ }^{44}$ e se, por acaso, encontrassem em seu caminho um condenado à morte, poderiam decidir

\footnotetext{
38 TITO LÍVIO. XXVI, 27, 14 discorre sobre a perversidade dos campanianos que "haviam tentado atingir o templo de Vesta, seu fogo eterno e o penhor (palladium) dado pelo destino ao império romano".

39 BORNECQUE, Henri; MORNET, Daniel. op. cit., p. 76.

40 HORÁCIO. Odes, 1,2,27.

41 CÍCERO. Pro Domo, 53.

42 Os lictores carregavam os fasces (feixe de varas em torno de um machado), símbolo do poder de Roma, e acompanhavam o rei e os magistrados nas cerimônias públicas. Foi apenas Tarquínio Prisco, quinto rei romano, quem introduziu tal uso.

43 Ser conduzido por vehiculum era privilégio reservado a apenas alguns, pois o caráter tortuoso das ruas romanas impedia que tal transporte fosse utilizado freqüentemente. Era de liteira que as pessoas em geral circulavam. Em 395 a.C., entretanto, como recompensa às matronas pela doação de ouro efetuada ao erário por ocasião das dificuldades provocadas pelas Guerras Púnicas, o Senado Romano autorizou que estas pudessem também circular por Roma utilizando vehiculum. Mais tarde, em 215 a.C. a Lex Oppia proibirá a utilização do iunctum vehiculum pelas mulheres, disposição esta que será revogada em 195 a.C. A propósito, veja-se MADEIRA, Eliane Maria Agati. La Lex Oppia et la condition juridique de la femme dans la Rome Républicaine, cit., p. 90.

44 PLÍNIO. História Natural, XXVIII,3.
} 
por salvar sua vida. ${ }^{45}$ Quanto a este apanágio, o de dispensar a aplicação da pena capital, parece-nos extremamente significativo atribuir a tais religiosas o poder de, em última análise, revogar decisão popular ou de um magistrado competente.

Aulo Gélio, ${ }^{46}$ um dos principais autores que nos instrui sobre a condição jurídica das Vestais, enfatiza que a aquisição de direitos da Vestal não é decorrente de capitis deminutio ou emancipação. No entanto, a partir de sua escolha pelo Pontífice Máximo, encerra-se sobre ela a patria potestas exercida pelo seu pater famílias e adquire esta sacerdotisa uma das suas principais prerrogativas jurídicas, a capacidade testamentária ativa.

Nos comentários de Labeão à Lei das XII Tábuas, reproduzidos por Aulo Gélio, ${ }^{47}$ encontra-se a seguinte afirmação: "A Vestal não é herdeira ab intestato de ninguém, e ninguém é seu herdeiro ab intestato; seus bens tornam-se propriedade pública. Ignorase por quais razões jurídicas seja dessa forma".

Para compreendermos a amplitude e o significado destas disposições, fazemse necessárias algumas considerações preliminares.

É sabido que as mulheres romanas, na qualidade de filhas solteiras ou casadas sine manu, eram admitidas à sucessão legítima (ab intestato) de seus pais em condições de absoluta paridade com os irmãos homens. Quanto às casadas cum manu, estas participariam da herança da família de seus maridos, in loco filiae. Tal participação da mulher no regime sucessório romano, aliás, tem sido apontada como pressuposto da denominada "emancipação" da mulher romana. ${ }^{48}$

No que diz respeito às Vestais, entretanto, sua exclusão do regime sucessório familiar, ou seja, a perda da sua condição de herdeira ab intestato, implica, conseqüentemente, na perda de sua originária qualidade de heres suus. Ressalte-se que sua impossibilidade de herdar caracterizar-se-ia mesmo diante de eventual ausência de heredes sui, o que nos leva a concluir que seu ingresso na vida sacerdotal ocasionasse o rompimento de seus vínculos de parentesco agnatício com sua família de origem. Outrossim, o fato de ninguém ser seu herdeiro ab intestato caracteriza a impossibilidade de se estabelecer, para efeitos sucessórios, parentesco civil entre a Vestal e seus familiares (uma vez que a vestal deve respeitar seu voto de castidade não há, em tese, que se falar em descendentes, heredes sui), agnados ou gentis. É bem verdade que, como acentou o eminente jurisconsulto Labeão, ignorava-se por quais razões jurídicas assim procedia-

\footnotetext{
45 PLUTARCO. Numa, X.

46 AULO GÉLIO. I, 12.9: Virgo autem vestalis simul est capta atque in atrium Vestae diducta et pontificibus tradita est, eo statim tempore sine emancipatione ac sine capitis minutione e patris potestate exit et ius testamenti faciundi adipiscitur.

47 AULO GÉLIO. I, XII.

48 CANTARELLA, Eva. op. cit., p. 134-135
} 
se. A dificuldade em compreender tal situação reside no fato de nela não estarem presentes as tradicionais razões jurídicas que provocam a extinção da patria potestas e, conseqüentemente, o rompimento da agnação: emancipação ou capitis deminutio. Esta parece ser, aliás, a essência do ius singulare que, conforme conceituado por Paulo, em D.1.3.16, "é aquele que foi introduzido pela autoridade dos que o constituíram, contra a coerência da razão, por causa de alguma utilidade".

De qualquer forma, as Vestais, ao deixarem de estar submetidas à patria potestas, adquirem imediatamente a capacidade testamentária (testamenti factio activa). ${ }^{49}$ Para exercitá-la, por óbvio, é necessário dispor de bens. Tais bens, como tivemos ocasião de verificar, não são provenientes de sucessão ab intestato, mas de doações ${ }^{50}$ ou de aquisições decorrentes de sua testamenti factio passiva.

Esta situação parece contribuir para a preservação do patrimônio familiar, princípio que norteou diversas das regras relativas ao direito sucessório romano. ${ }^{51} \mathrm{O}$ pater familias, assim, tem total autonomia para decidir se contemplará ou-não sua descendente com alguns bens. Sabe-se que costumeiramente o pater familias, assim que sua filha adentrasse na vida religiosa, conferia-lhe alguns bens a título de pecúlio. ${ }^{52}$

Para a compreensão da importância da capacidade testamentária das Vestais, é oportuno ressaltar que foi considerada absoluta a incapacidade de testar daquelas mulheres que não se dedicavam à vida religiosa, exceto daquelas que houvessem sofrido a capitis deminutio mínima. Segundo Gide, ${ }^{53}$ a explicação de tal fato deve-se ao seguinte: os atos inter vivos podem ser necessários ou úteis à mulher que pode praticá-los mediante a autorização de seu tutor, ainda que possam acarretar à família um prejuízo indireto. Ao contrário, o testamento não representa para a mulher qualquer benefício e tem por única finalidade a privação do patrimônio familiar. Ora, o tutor protege a família e não a mulher. Nesse sentido, é visto como guardião dos interesses da família. Dessa forma, com relação à mulher que sofreu a capitis deminutio e, conseqüentemente, ingressou em uma

\footnotetext{
49 A esse propósito, VOLTERRA, Edoardo. Istituzioni di Diritto Romano. Roma: 1961. p. 108 n.1 acentua que as Vestais não podem ser consideradas sui iuris pois deixam de estar submetidas ao poder de seu pater familias para se sujeitarem à autoridade do Sumo Pontífice.

50 Ressalte-se, outrossim, que Lívio 1.20.3 faz referência à instituição, pelo rei Numa, de um público estipêndio para que as Vestais pudessem dedicar-se exclusivamente à vida sacerdotal. Além disso, fontes epigráficas (CIL 6.10848) atestam que a soma proveniente de multas sepulcrais era entregue às Vestais.

51 Nesse sentido, CANTARELLA, Eva. op. cit., p. 66, ao discorrer sobre a admissão feminina à sucessão no patrimônio familiar enfatiza que a necessidade do tutor mulierum representou um modo de tornar a mulher "detentrici provvisorie del patrimonio familiare", posto que a tutela, ao menos em época arcaica, não era um instituto protetor, mas potestativo. Servia, assim, para impedir que a mulher dissipasse o patrimônio familiar.

52 MOMMSEN,Teodoro. Derecho Penal Romano. Tradução do original alemão Römisches Strafrecht, Leipzig, 1899 por Pedro Dorado Montero. Madrid: Temis, 1999. p. 16 fala em pecúlio "equiparado ao patrimônio". Estes bens podiam ser eventualmente apropriados por ordem do Pontífice Máximo como forma de sanção aplicada às Vestais.

53 GIDE. Étude sur la condition privée de la femme. Paris: Larose et Forcel, 1885. p. 109-110.
} 
nova família, o que provocou o rompimento do parentesco com sua família de origem e a privação de seus antigos agnados da tutela e de participação em sua sucessão, permitir-lhe testar significa possibilitar que tais agnados, que não são mais seus herdeiros presuntivos, possam, por testamento, ter participação em seus bens.

Ressalte-se que a capitis deminutio feminina não necessariamente é decorrente de um casamento cum manu. Poderia ser obtida por meio de uma coemptio fiduciaria, descrita por Gaio, ${ }^{54}$ pela qual se submetia a mulher à manus de um estranho com o qual houvera sido estabelecido, por meio de um pacto de fidúcia, a obrigação de emancipá-la. Trata-se da fiduciaria coemptio testamenti faciendi gratia.

Observa-se, assim, que a capacidade feminina para redigir testamento está subordinada à auctoritas de seu tutor. Trata-se de uma regra do ius commune. E aí se encontra outro ponto distintivo da condição jurídica das Vestais, as quais não estavam submetidas a tal tutela.

O jurista Gaio, nas célebres Institutas (Gai. I,145), atribui a dispensa da tutela mulierum, que segundo ele já estava expressa nas XII Tábuas, ${ }^{55}$ à reverência (in honorem sacerdotii) que os antigos (veteres) prestavam ao sacerdócio de Vesta. :

Gai. 1.145:

Loquimur autem exceptis virginibus Vestalibus, quas etiam veteres in honorem sacerdotii liberas esse voluerunt, itaque etiam lege XII tabularum cautum est.

Do que dizemos, porém, se excetuam as virgens Vestais, que os antigos quiseram livres em honra do sacerdócio, o que foi, aliás, ordenado pela lei das XII Tábuas.

Plutarco, ${ }^{56}$ por sua vez, atribui ao Rei Numa Pompílio a dispensa da tutela das Vestais o que não indica, necessariamente, divergência em relação à posição de Gaio, posto que o jurista do século II d.C. já atribuía aos veteres tal orientação.

É ainda na obra do historiador grego Plutarco que encontramos preciosas informações a respeito dos diversos privilégios outorgados às Vestais pelo Rei Numa

\footnotetext{
54 Gai. I, 115.

55 SOLAZZI, Siro. La liberazione delle vestali dalla tutela in Gai. 1.145. Studia et Documenta Historiae et Juris, Roma, v. 9, 1943, p. 113 e ss. apud SACCHI, Osvaldo. Il privilegio dell'esenzione dalla tutela per le Vestali (Gai.1.145). cit., p. 326 entende ser interpolado este texto gaiano. GUIZZI, Francesco. Aspetti giuridici del sacerdozio romano. p. 18 e 19 por sua vez, acredita que o termo veteres seja uma referência à jurisprudência pontifical pré-decenviral e que se possa atribuir aos mores maiorum a dispensa da tutela das Vestais. Quanto à possível existência, na Lei das XII Tábuas, desta determinação legal, SACCHI, cit., p.334 entende tratar-se de uma referência de Gaio não ao texto específico da lei, mas ao resultado de uma interpretação extensiva de uma norma das XII Tábuas efetuada pelos juristas que a incorporam ao texto da lei, tal qual expresso em D.50.16.120.

56 PLUTARCO. Numa, X.
} 
Pompílio. De acordo com o relato daquele historiador, poderiam aquelas sacerdotisas redigir testamento ainda durante a vida de seus pais e praticar atos jurídicos sem a assistência de um tutor, assim como as mulheres que houvessem dado à luz três filhos. ${ }^{57}$ Interessante observar que também Gaio, ao tratar deste tema, alude ao instituto do ius trium vel quattuor liberorum.

Cássio Dion, em sua História, ${ }^{58}$ diferentemente, atribui apenas a Augusto ${ }^{59} \mathrm{a}$ autoria da determinação da regra jurídica, segundo a qual as sacerdotisas de Vesta estavam isentas da tutela. Curiosamente, refere-se também ao ius trium vel quattuor liberorum. ${ }^{60}$

Consideramos que o fato dos três autores, metodologicamente, associarem a dispensa da tutela das Vestais à dispensa da tutela em razão do ius liberorum reflita o compartilhamento de uma mesma concepção quanto à importância dos fatos que conferem à mulher maior dignidade. Assim como as Vestais, que prestam valiosa contribuição a Roma, foram beneficiadas pela isenção da tutela, algumas mulheres (as mães de três ou quatro filhos) receberam o mesmo privilégio em razão de um grande serviço prestado à res publica (ao Império, mais especificamente). Tal fato reforça a excepcionalidade do instituto, assim como o apreço que os romanos nutriam por dois valores: a castidade das Vestais e a fecundidade das matronas.

Peppe ${ }^{61}$ ao ressaltar a "indiscutivel subjetividade patrimonial feminina na experiência jurídica romana desde os primórdios", pondera que, sob essa perspectiva, a tutela representaria apenas o controle desta capacidade patrimonial.

No que diz respeito ao ius testandi feminino, complementa o respeitado Autor, a prescindir do privilégio concedido às vestais em idade antiqüíssima, a mais antiga notícia que se tem de um testamento feminino é aquele da liberta Hispala Fecênia (Lívio, XXXIX,9,7) a favor de seu namorado Ebúcio, em que não há menção à capitis deminutio ou à coemptio fiduciaria. Com efeito, as libertas necessitavam, para fazer testamento, apenas da auctoritas de seu tutor, conforme Gai., III,43.

Do ponto de vista prático, como poderia a Vestal exercitar sua testamenti factio activa?

\footnotetext{
57 Durante o reinado de Augusto, a Lex Julia et Papia Poppea, com o propósito de evitar uma crise demográfica em Roma, dentre outras providências, dispensou da tutela as mulheres que houvessem dado à luz três (se ingênuas) ou quatro filhos (se libertas). Trata-se do denominado ius trium vel quattuor liberorum estabelecido pela legislação matrimonial de Augusto (leges Iulia et Papia Poppaea).

58 Cássio Dion, 56.10.2 apud SACCHI, Osvaldo. Il privilegio dell'esenzione dalla tutela per le Vestali (Gai.1.145). cit., p. 318.

59 Ressalte-se que Augusto (Cássio Dio, 55.22.5), numa época em que poucos pais estavam satisfeitos em ceder suas filhas ao sacerdócio, permitiu que também as libertas pudessem tornar-se Vestais.

${ }^{60}$ Esta similaridade já havia sido notada por SACCHI, Osvaldo. op. cit., p. 7.

${ }_{61}$ PEPPE, Leo. Posizione giuridica e ruolo sociale della donna romana in età repubblicana. Milano: Giuffrè, 1984. p. 43 e ss.
} 
Tendo em conta que a primitiva forma de testamento praticada pelos romanos, qual seja, aquela realizada diante dos comícios por cúrias, não era acessível às mulheres pelo fato destas não poderem participar dos referidos comícios e que o testamento per aes et libram que permitiu às mulheres em geral exercer a testamenti factio activa mediante a intervenção e consentimento (auctoritas) de seu tutor foi somente introduzido entre a segunda metade do século IV e a primeira metade do III século antes de Cristo, atribuir às vestais a testamenti factio activa antes da incorporação daquela forma de testamento privado ao Direito Romano significa: a) admitir sua participação nos comícios (fato este não-comprovado pelas fontes) ou b) admitir que houvesse um tipo específico de testamento a elas reservado.

Com relação à capacidade das Vestais de herdar, a primeira Vestal a ter recebido esta prerrogativa foi Caia Tarrácia. ${ }^{62}$ A Lex Horatia de Taracia virgine vestali concedeu, especialmente pelo fato desta haver doado ao povo romano o Campus Tiberinus, insignes prerrogativas a esta Vestal, que depois foram estendidas às demais Vestais, como o direito de depor em justiça, de exercer o papel de testemunha em atos solenes e de ser testabilis. A data e o conteúdo desta lei do cônsul Horatius são legendários, ${ }^{63}$ mas acreditase que tal lei tenha sido promulgada em 449 a.C.

4. Aspectos jurídicos relacionados ao rompimento do voto de castidade das Vestais: stuprum e incestum

Os romanos denominavam incestum a prática de relações sexuais entre pessoas unidas por vínculo de parentesco ou afinidade, assim como a violação do voto de castidade das sacerdotisas Vestais. Trata-se de um delito sexual caracterizado pela violação das obrigações religiosas dos cidadãos ou de uma Vestal, posto que o direito sacro considerava impura (incestus) uma união sexual desta natureza. ${ }^{64}$

O termo stuprum, por sua vez, designava em Roma a prática de relações sexuais ilícitas, ou seja, com mulheres honradas e não-casadas (virgo vel vidua). ${ }^{65}$ As fontes, ocasionalmente, utilizam esta palavra para indicar o ato sexual responsável pelo rompimento do voto de castidade das Vestais. Diferentemente do significado moderno não se refere o estupro (stuprum) à prática de relações sexuais não-consentidas.

As conseqüências relacionadas ao rompimento do voto de castidade das Vestais vêm relatadas por Plutarco ${ }^{66}$ de modo bastante minucioso.

\footnotetext{
AULO GÉLIO. VII, 7,4.

ROTONDI, Giovanni. op. cit., p. 206.

MOMMSEN, Teodoro. op. cit., p. 427.

65 Cf. DI SALVO. Stuprum. In: Dizionario giuridico romano. Napoli: Simone, 2000.

${ }_{66}$ PLUTARCO. Vidas Paralelas, Numa, X.
} 
A Vestal que eventualmente perdesse a virgindade era sepultada viva junto à Porta Colina. ${ }^{67} \mathrm{Na}$ parte inferior da extensa porção de terra adjacente à Porta, construíase uma pequena caverna que pudesse ser acessada do alto. Nela colocavam-se uma cama com coberta, luz e um pouco de alimento: pão, água, leite e óleo. Apenas o suficiente para que a Vestal a ser inserida naquele local não morresse imediatamente de fome. A condenada era amarrada sobre uma liteira e conduzida à presença do Pontífice Máximo. Atravessavam então a praça, na qual uma multidão entristecida, em grande silêncio, a tudo assistia. Plutarco enfatiza ser este um "espetáculo horrível” e ressalta que a cidade não tem outro dia mais dolente. Estando a liteira à beira da entrada da caverna, são rompidas as amarras e o Pontífice Máximo, com as mãos alçadas ao céu, realiza algumas orações secretas. Em seguida, é a jovem colocada sobre a escada que conduz à caverna e, nesse momento, o Pontífice se retira com os demais sacerdotes. Descida a Vestal, suspende-se a escada e, com muita terra se recobre a abertura.

Plutarco $^{68}$ também nos informa que aquele que se esconder sob o leito de uma Vestal será condenado à morte. Além disso, a prática de infrações menores pelas sacerdotisas confere ao Pontífice Máximo o direito de fustigá-las nuas em local escuro, no qual era instalada uma cortina diante da Vestal para ocultar sua nudez.

4.1 Notícias de alguns processos republicanos envolvendo Vestais. Uma breve análise

A apuração da desobediência ao dever de castidade de uma Vestal despertava grande comoção pública, provável razão da presença, nas fontes, de diversas notícias desta natureza.

Com o intuito de examinar o procedimento penal ao qual tais processos estavam submetidos, selecionamos alguns dos mais expressivos episódios desta espécie que se desenrolaram no período republicano. ${ }^{69}$

1) Tito Lívio IV, 44, 11-12:

Eodem anno Postumia virgo Vestalis de incestu causam dixit, crimine innoxia, ab suspicione propter cultum amoeniorem ingeniumque liberius quam virginem decet parum abhorrens. Eam ampliatam, deinde absolutam pro collegii sententia pontifex maximus abstinere iocis colique sancte potius quam scite iussit.

\footnotetext{
67 A Porta Colina era uma das portas da Muralha Serviana, a mais antiga muralha urbana de Roma, que conduzia à Via Salaria. De acordo com a tradição, tal muralha foi construída pelo rei Sérvio Túlio.

68 PLUTARCO. Vidas Paralelas, Numa, X.

69 Uma relação completa de todos os processos envolvendo Vestais pode ser encontrada em GIANNELLI, Giullio. Il sacerdozio delle Vestali romane. Firenze: Galetti e Cocci, 1889. 913, p. 81 n.5. Nesta sede nos restringimos àqueles individualizados por PEPPE, Leo. op. cit., p. 118 e seg., considerados os mais expressivos.
} 
Nesse mesmo ano, a vestal Postúmia discursou em uma causa de incesto. Ela era inocente, mas seus trajes excessivamente elegantes e seu modo de expressar-se um tanto livre para uma virgem não a livraram de suspeitas. ampliada a causa e depois absolvida por decisão do colégio, determinou o pontífice máximo abster-se ela dos gracejos e a vestir-se com menos elegância e mais modéstia.

Em 420 a.C a Vestal Postúmia é acusada de incestu. Após ter sido "ampliada a causa" mediante a análise de todos os sacerdotes que compõem o colégio pontifical, foi Postúmia absolvida.

Era na Regia, residência oficial do sumo pontífice que tal processo se desenrolava. Nos processos contra as Vestais intervinham regularmente todos os pontífices. Ouvidos tais conselheiros, o sumo pontífice proferia sua decisão.

Ressalte-se que o modo bastante livre da Vestal expressar-se e a suntuosidade de seus trajes contribuíram para o levantamento de suspeitas em relação a ela. Declarada sua inocência, o processo culminou com a recomendação do Pontífice Máximo de comportar-se com maior reserva.

Segundo Mommsen, as Vestais, como filhas da comunidade que eram, estavam submetidas originariamente ao poder de correção do Rei e, posteriormente, ao poder do Pontífice Máximo. ${ }^{70}$ Tal sacerdote exerceu seu poder punitivo sobre as sacerdotisas até que o Cristianismo fosse declarado religião oficial do Império, no âmbito da denominada "punição doméstica", numa clara analogia àquele poder exercido pelo pater familias em relação aos seus subordinados.

Com relação ao homem co-delinqüente, este também estava sujeito ao julgamento pontifical, de modo que os limites da punição doméstica se alargaram a ponto desta se transformar em um verdadeiro procedimento jurídico-formal, pelo qual o sacerdote adquiria o direito de vida e de morte também sobre o cúmplice da Vestal.

2) Tito Lívio VIII, 15, 7-8:

Eo anno Minucia Vestalis, suspecta primo propter
mundiorem iusto cultum, insimulata deinde apud pontifices
ab indice servo, cum decreto eorum iussa esset sacris
abstinere familiamque in potestate habere, facto iudicio viva
sub terram ad portam collinam dextra viam stratam defossa
scelerato campo, credo ab incesto id ei loco nomem factum.

Naquele ano, a vestal Minúcia, que já se tornara suspeita por seus trajes excessivamente mundanos, foi denunciada aos

\footnotetext{
70 MOMMSEN,Teodoro. Derecho Penal Romano. Tradução do original alemão Römisches Strafrecht, Leipzig, 1899 por Pedro Dorado Montero. Madrid: Temis, 1999. p. 13.
} 
pontífices pelo testemunho de um escravo. Os pontífices, por um decreto, ordenaram-lhe que se abstivesse do exercício dos ritos sacros e que deixasse os servos sobre a sua potestate. Realizado o julgamento, a vestal foi enterrada viva perto da porta Colina, à direita da rua pavimentada no Campo Celerado, assim chamado, creio, por causa do crime de incesto da vestal.

Em 337 a.C., a Vestal Minúcia é condenada apud pontifices e sepultada viva junto à Porta Colina, por incesto.

O processo iniciou-se a partir da denúncia de um escravo, o que confirma a tese de que o sistema da punição doméstico era inquisitivo e a interposição da ação se dava mediante denúncia. ${ }^{71}$

Novamente, a utilização de trajes mundanos pela Vestal levantou suspeita quanto a sua honestidade. A Vestal, sabe-se, embora permanecesse a maior parte do tempo enclausurada, no desempenho de suas funções sagradas, saía deste ambiente para assistir às cerimônias públicas e espetáculos. ${ }^{72}$ Certamente, são nestas ocasiões que suas vestimentas podem ser observadas e, embora houvesse um "traje padrão" para tais mulheres, alguns detalhes poderiam ser acrescentados às suas vestimentas que chamassem indevidamente a atenção alheia.

Observe-se que durante o desenrolar deste processo, a Vestal, suspeita de incestum, manteve-se afastada de suas funções sacramentais. Além disso, recebeu a ordem de manter seus servos sob a potestate (familiamque in potestate habere) do Sumo Pontífice. Tal determinação tem por objetivo evitar que a Vestal manumitasse tais escravos que, desse modo, deixariam de ser torturados para declararem a verdade sobre os fatos. Além disso, evita-se o risco dos escravos, mantendo-se junto da Vestal, se predisporem em seu favor. ${ }^{73}$ Isso nos revela três aspectos importantes. Um, de natureza patrimonial, comprovando que a Vestal tem bens próprios, nesse caso específico, escravos. Outro, de natureza penal: a admissão da prática de tortura em relação aos escravos. Por fim, nota-se que, no que diz respeito à condição jurídica do escravo, era reconhecida sua capacidade de ser testemunha, também confirmada por um texto de Valério Máximo (III,7,9), exposto adiante.

\section{3) Lívio XXII,57,2}

Territi etiam super tantas clades cum ceteris prodigiis, tum

\footnotetext{
71 MOMMSEN,Teodoro. Derecho Penal Romano. Tradução do original alemão Römisches Strafrecht, Leipzig, 1899 por Pedro Dorado Montero. Madrid: Temis, 1999. p. 17.

72 CÍCERO. Pro Murena, 35.73 expõe que a Vestal Licínia, em 63 a.C., cede seu lugar de honra nos espetáculos de gladiadores a Licínio Murena, candidato ao consulado.

73 Cf. MORESCHINI, notas à obra de TITO LíVIO. Storia di Roma dalla sua fundazione. Milano: Rizzoli, 1982. p. 392.
} 
quod duae vestales eo anno, opimia atque floronia, stupri compertae et altera sub terra, uti mos et, ad portam collinam necata fuerat, altera sibimet ipsa mortem consciverat; $l$. cantilius scriba pontificius, quos nunc minores pontifices apellant, qui cum floronia stuprum fecerat, a pontifice maximo eo usque virgis in comitio caesus erat ut inter verbera exspiraret.

Além de tamanhos desastres, o que provocou pânico foi a circunstância de, nesse ano, além de outros prodígios, as vestais Opímia e Florônia terem sido assinaladas de stuprum: segundo o costume uma foi enterrada viva junto à Porta Colina, a outra se matou. Lúcio Cantílio, escriba pontifício (dos que hoje se chamam "pequenos pontífices") que praticou o stuprum com Florônia, sofreu no comício flagelação por mão do pontífice máximo até expirar sob os golpes.

Em 216 a.C., as Vestais Opímia e Florônia são condenadas por stuprum. Opímia é sepultada viva junto à Porta Colina e Florônia comete suicídio. O escriba pontifical L. Cantílio, cúmplice de Florônia, é fustigado até a morte por ordem do Pontífice Máximo.

Veja-se que o desvio de comportamento das Vestais provocava pânico na sociedade, pois se acreditava que a harmonia de Roma e sua proteção dos deuses estivessem relacionadas à manutenção da honra e do respeito destas sacerdotisas. $\mathrm{O}$ rompimento da castidade de uma Vestal é interpretado, assim, como assunto de natureza coletiva e pública. Tais acontecimentos se relacionaram, ainda, a uma época de grande instabilidade política, no decorrer da Segunda Guerra Púnica e, especificamente, foram associados à sucessão de prodígios que se multiplicavam.

4) Plínio, História Natural, XXVIII, 3, discorrendo sobre o poder das palavras e das fórmulas em rituais sagrados afirma:

Conserva-se a oração recitada pela Vestal Túcia que, acusada de incesto, carrega consigo, em uma peneira, água proveniente do Tibre, no ano de Roma de 609.

Sobre o mesmo episódio, Valério Máximo VIII. 1.5, ao tratar dos processos públicos insignes que culminaram, por razões diversas, com a absolvição dos réus ( $D e$ iudiciis publicis insignibus quibus absoluti) informa:

Eodem auxilii genere Tucciae, virginis Vestalis, incesti criminis reae, castitas infamiae nube obscurata emersit: quae conscientia certae sinceritatis suae, spem salutis ancipiti argumento ausa petere est; arrepto enim cribro, "Vesta, inquit, si sacris tuis castas semper admovi manus, effice, ut hoc hauriam e Tiberi aquam, et in aedem tuam 
perferam". Audaciter et temere jactis votis sacerdotis, rerum
ipsa natura cessit.

Graças a uma semelhante proteção, ${ }^{74}$ Túcia, jovem vestal, acusada de incesto, vê sua reputação sair ilesa da suspeita de infâmia que a atingia. Segura de sua consciência e sinceridade, ela ousou confiar a esperança de sua absolvição a uma prova bastante perigosa: segurando uma peneira disse ela: "Vesta, se eu sempre me aproximei de seu altar com as mãos puras, faça que nesta peneira eu derrame a água do Tibre e traga-a até seu templo". A audácia e a temeridade presentes nos desejos da sacerdotisa permitiu Sua realização pela natureza.

A Vestal Túcia, graças a um prodígio é absolvida em 145 a.C. Tal fato apresenta similaridade com outro célebre acontecimento. Trata-se do episódio envolvendo a Vestal Cláudia que também foi beneficiada por um prodígio, na ocasião da recepção da Magna Mater, a deusa Cibele, em Óstia. Embora as fontes não nos esclareçam suficientemente se Cláudia fosse uma matrona ou uma Vestal, o certo é que pairava sobre ela a suspeita de incesto. De acordo com o oráculo de Delfos a embarcação contendo a representação da deusa deveria ser acolhida por um vir optimus acompanhado de um cortejo de mulheres honestas. Sêneca ${ }^{75}$ é quem por primeiro considera que Cláudia fosse uma sacerdotisa. Ao chegar à embarcação em Óstia, na foz do Tibre, a nave pára e ninguém consegue conduzi-la até Roma. Cláudia, então, invoca a ajuda divina e, amarrando seus cabelos à embarcação a conduz, sem esforço até Roma, o que foi interpretado como prova de sua inocência.

5) Em 113 a. C. as Vestais Emília, Licínia e Márcia são acusadas de incesto. O Pontífice Máximo, L. Metello, absolve Márcia e Licínia, mas condena Emília.

No entanto, o tribuno da plebe Sestio Pedúceo, por meio de um plebiscito, incumbe o intransigente pretor L. Cássio Ravilla ${ }^{76}$ como quaesitor para apurar o caso, o qual condena e determina a morte das duas Vestais anteriormente absolvidas e tantas outras cujos nomes não foram conhecidos pela história.

Veja-se que, nesse caso, a sentença pontifical veio confrontada por um plebiscito (Plebiscito Peduceo) para ser reformada in peius, de modo a não se caracterizar a exclusividade da jurisdição pontifical. Trata-se da Lex Peducaea de incestu virginum

\footnotetext{
74 Em Valério Máximo, VIII, 1, 4 atribui-se também a uma proteção divina a absolvição de P. Claudius acusado de injúria à pátria. Com efeito, uma surpreendente tempestade interrompeu a audiência na qual o povo, bastante irritado, já houvera dado sinais de sua condenação. No entanto, a crença de que tal manifestação da natureza representasse uma interferência divina favorável ao réu impediu que se desse, em outra oportunidade, continuidade ao procedimento judiciário e Claudius foi então absolvido.

75 SÊNECA. Framm. 80.

76 CÍCERO. Brutus, 43, 160.
} 
Vestalium ${ }^{77}$ plebiscito do tribuno Sesto Pedúceo que instituiu uma quaestio extraordinaria de incestu para renovar o processo contra as Vestais Emília, Márcia e Lícínia. ${ }^{78}$

Valério Máximo (III,7,9) relata que o célebre orador M. Antonio, tendo partido na qualidade de questor para a Ásia foi acusado de incesto diante da quaestio presidida por L. Cassius e, estando ainda em Brindisi, opta por retornar a Roma e comparecer, sendo imediatamente provada sua inocência, apesar de poder ter invocado o benefício da Lex Memmia que proibia que acusações fossem impostas contra qualquer cidadão ausente a serviço da República.

Ainda em Valério Máximo (VI,8,1) retoma-se este tema para ressaltar a fidelidade do escravo de M. Antonio que, embora duramente torturado durante o julgamento (os acusadores de M. Antonio afirmavam que o escravo, com uma lanterna à mão, havia acompanhado seu dono ao encontro com a Vestal), negou a participação de seu senhor no alegado crime.

Segundo Peppe, ${ }^{79}$ "si trata di um episodio di portata rivolucionaria". Afirma ainda o referido Autor que este episódio demonstra que, diante de certas circunstâncias, a prerrogativa consuetudinária da exclusividade da jurisdição pontifical em matéria de incestus das Vestais e de seus cúmplices pode vir a ser afastada, especialmente em casos de grande relevância política e constitucional e de menor valor religioso. Talvez tenha contribuído para a relevância do episódio o fato de ter sido acusado como cúmplice de uma Vestal um questor.

De qualquer modo, a absolvição pela jurisdição pontifical não era obstáculo para que se pudesse intentar um processo criminal público. ${ }^{80}$

No que diz respeito à pena capital, não há menção, nas fontes de oposições por parte dos condenados, à jurisdição pontifical. Isso, entretanto, não nos autoriza a concluir que houve proibição de provocatio e exclusividade da jurisdição pontifical, mas tão-somente que era costume privilegiar a jurisdição pontifical. ${ }^{81}$ Além disso, ainda segundo Peppe ${ }^{82}$ dada a natureza do incestum das Vestais, sempre há cúmplices masculinos, os quais eram também condenados à morte, o que leva este Autor a concluir que se houve na Antiguidade a proibição de provocatio ou de intercessio, esta era ratione criminis e não em decorrência do sexo.

Curioso observar que enquanto a punição doméstica exercida em relação às mulheres sofreu atenuações no período Republicano, por conta da denominada

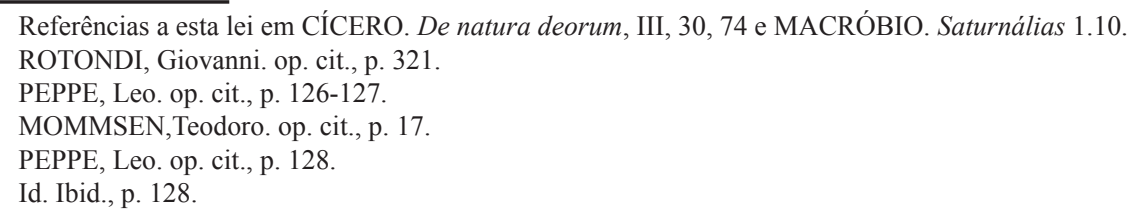


“emancipação feminina”, tal punição relativamente às Vestais, diferentemente, exacerbouse, pois foi cada vez maior o medo que os romanos nutriam dos deuses. ${ }^{83}$

5. Reflexões finais

Assim como Cantarella, ${ }^{84}$ considero que as conclusões "hanno sempre un'aria un po' imperiosa. Le conclusioni vere sono quelle che ciascuno trae per suo conto". Por isso passo a expor apenas algumas considerações finais, que poderão, quiçá, ser objeto de múltiplas reflexões pessoais.

A condição jurídica das Vestais apresentou diversas nuances ao longo da História romana, todas elas, entretanto, marcadas pela generalizada visão da sacerdotisa de Vesta como alguém responsável por um sanctissimum sacerdotium. Desta forma, poderse-ia dizer que a evolução do status das Vestais trilhou um percurso, cujo ponto originário está representado pelos mores maiorum e pelas controversas leis régias até a existência de regras formais e específicas, proporcionais à importância que, gradualmente, assume o culto nacional, do qual o Culto à Vesta constitui um dos aspectos.

A sacerdotisa Vestal, ao assumir "privilégios", não os está adquirindo como apanágios que a colocam na situação de mulher emancipada. Tais prerrogativas constituem meios de reforçar a aura de divindade de que estão cercadas e, na medida em que facilitam o exercício de suas funções, trazem consigo uma utilidade pública. Tudo confirmando a tese, segundo a qual publicum ius in sacris, in sacerdotibus, in magistratibus constitit (D.1.1.1.2)

Isso parece explicar o fato da deusa Vesta ser, ordinariamente, representada por uma sacerdotisa vestal. Esta é a própria corporificação daquela e como tal deve expressar alguns valores caros aos romanos, como a simplicidade, a moderação, a discrição, a pudicitia.

São Paulo, setembro de 2008.

\section{Referências}

BORNECQUE, Henri; MORNET, Daniel. Roma e os romanos: literatura, história, antiguidades. São Paulo: EDUSP, 1977.

BRANDÃO, Junito de Souza. Dicionário Mítico-Etimológico da Mitologia e da Religião Romana. Petrópolis: Edunb, 1993.

\footnotetext{
83 MOMMSEN,Teodoro. op. cit., p.16.

${ }^{84}$ CANTARELLA, Eva. op. cit., p. 133.
} 
CANTARELLA, Eva. L'ambiguo malanno. Milano: Einaudi, 1995.

CATALANO, Pierangelo. Populus Romanus Quirites. Torino: Giappichelli, 1974.

DI SALVO. Stuprum. In: Dizionario giuridico romano. Napoli: Simone, 2000.

GIANNELLI, Giullio. Il sacerdozio delle Vestali romane. Firenze: Galetti e Cocci, 1889.

GIDE. Étude sur la condition privée de la femme. Paris: Larose et Forcel, 1885.

HUMBERT, Jules. Histoire illustrée de la littérature latine: précis méthodique. Paris/Toulouse: H. Didier, 1932.

MADEIRA, Eliane Maria Agati. Advogadas Romanas Republicanas artigo apresentado na 59 ème Séssion de la Société Fernand de Vischer pour 1'Histoire des Droits de 1'Antiquité. Revista da Faculdade de Direito da Universidade de São Paulo, São Paulo, v. 101, p.87-107, jan./dez. 2006.

MADEIRA, Eliane Maria Agati. Algumas considerações sobre a prática feminina de envenenamentos na Roma Republicana. Revista da Faculdade de Direito de São Bernardo do Campo, 2004

MADEIRA, Eliane Maria Agati. La lex Oppia et la condition juridique de la femme dans la Rome Républicaine. Revue Internationale des droits de l'antiquité, LI, Bruxelles, p. 87-99, 2004

MOMMSEN,Teodoro. Derecho Penal Romano. Tradução do original alemão Römisches Strafrecht, Leipzig, 1899 por Pedro Dorado Montero. Madrid: Temis, 1999.

MOMMSEN,Teodoro. Derecho Penal Romano. Tradução do original alemão Römisches Strafrecht, Leipzig, 1899 por Pedro Dorado Montero. Madrid: Temis, 1999.

PEPPE, Leo. Posizione giuridica e ruolo sociale della donna romana in età repubblicana. Milano: Giuffrè, 1984.

ROTONDI, Giovanni. Leges publicae populi romani. Hildeshei: Olms, 1966.

SACCHI, Osvaldo. Il privilegio dell'esenzione dalla tutela per le Vestali (Gai.1.145). Revue Internationale des Droits de L'antiquité, Liège, v. 3, n. 50, p. 317-359, 2003.

SCHEID, John. Roma al femminile, Claudia la vestale. Bari: Laterza, 1994.

TITO LÍVIO. Storia di Roma dalla sua fundazione. Milano: Rizzoli, 1982. 